\title{
Opinion
}

\section{The Migration Crisis: No Human is Illegal}

\author{
GODFREY BALDACCHINO AND CARMEN SAMMUT
}

The migrants seeking to enter Europe - we surely cannot blame them for leaving their homeland. What would we not do to save our families or ourselves from economic ruin, religious or political persecution, civil strife, poverty, or long-term unemployment? Many make a rational choice. They move to close havens: thousands of Syrians shelter in Jordan, Lebanon and Turkey. But desperation and aspiration drive thousands to the cluster of safe and affluent European states that lie temptingly close, and who need skilled eager workers to secure the future of their economies and welfare regimes. Such a 'push-pull' scenario has driven human mobility throughout the ages.

Sheer figures and images of thousands of anonymous arrivals tend to foster fear and panic. It took the iconic picture of the limp body of three-year-old Syrian Aylan Kurdi, washed up on a Turkish beach, to stir many people's feelings. The wave of humanitarianism in support of refugees shows that people bond with people, at least until compassion fatigue sets in. The response of many Icelandic families to host Syrians, and the hundreds of Austrians that organised convoys to help those refugees travelling on foot, speak volumes.

If the dilemma for states lies in how to respond, then two generic types of response have materialised. The first, adopted by Hungary, is to push and force these migrants away, make it clear that they are unwelcome, build walls and fences to (try to) keep them out of the country with the promise to organise aid outside European Union soil. This approach is the one preferred by a vocal minority that has managed to twist the machinery of many European governments, occupied by nervous politicians unsure of how to respond to panic-stricken constituencies that are open to rabid 21 st century nationalism.

The second is the response adopted by Germany, driven by an outpouring of public sympathy, but also by calculated reasoning, that may find this country welcoming some 800,000 immigrants during 2015 . The plan is to help them quickly integrate into, and contribute to, German society and the economy. Chancellor Angela Merkel has a historic challenge to transform what has been dubbed as 'a refugee crisis beyond proportion' into an opportunity. The Syrian refugees may prove to be a welcome injection of skill, creativity, and the sheer will to survive in a Germany that is currently experiencing the lowest birth rate in Europe. Initially, most immigrants would be a drain on the

Correspondence Address: Godfrey Baldacchino, Department of Sociology, University of Malta, Msida MSD 2080, Malta. Email: gbaldacchino@upei.ca; Carmen Sammut, Department of International Relations, University of Malta, Msida MSD 2080, Malta. Email: carmen.sammut@um.edu.mt 
state: they will require food, shelter, support, health care; but wait and look at them after a few years, or even months - most would be giving back to the state.

One other dilemma lies in the very mobility of migrants: in the post-Westphalian world, nation states police their borders to secure their sovereignty. So while globalisation processes express an unprecedented and unrestrained momentum, most states have only lowered barriers to global communications, material goods and finance; not for human movement (other than tourism). Most governments have very clear rules regarding how and which non-nationals may enter, settle and/or work within their borders; the idea is to encourage those seen to be in a position to contribute to the local economytypically the best educated and the richest - to come and settle, while keeping out all the rest.

In spite of borders and regulations, national governments are frequently caught between a rock and a hard place. First, there is the difficult business of sifting through the thousands of hopeful individuals waiting at their doors. In this process, they are obliged to adhere to international commitments, especially the 1951 Refugee Convention and its principle of non-refoulement. Even in the case of economic migrants, repatriation is never plain sailing, especially in times of mass waves of international migration that often leave governments helpless. Any attempt at migration management that is operationalised via brutal police or military interventions, detention, or repatriation often constitutes human rights breaches. Such actions also prompt media outcries and civil society protests that cause much embarrassment. When some EU states took this route, they were deemed to jeopardise the very heart of European values.

On the other hand, governments cannot ignore public anxieties. Having to face periodic elections, they must reassure their publics by resorting to some kind of enforcement. Otherwise they are accused of powerlessness: politicians cannot afford to be seen to be so helpless; and yet they are.

The one correct response is humanitarian in the short term, with social and economic integration to follow. Integration policies are not uniform in all the EU states, as revealed by the Migrant Integration Policy Index. Integration is a massive challenge but it is the only way forward. The ghettoisation of migrant communities breeds resentment, poverty and security risks. Europe must invest in integration. New immigration countries can learn from both the mistakes and the good practices of others. Ways in which greater diversity and inter-communitarian dialogue can contribute to European advancement need to be sought and implemented.

Composed as it is of both migrant-sending and migrant-receiving countries, the Commonwealth is well placed to lead an international movement to decriminalise migration and instead help put in place more orderly mechanisms that note current and projected human movements across countries. Bilateral and multilateral negotiations, such as structures that issue humanitarian visas, if undertaken in good faith, may be able to provide channels of opportunity for human mobility with less peril for the migrants and better outcomes for the receiving states.

Ironically, the world is currently experiencing the biggest wave of refugees since World War II, just as the 70th anniversary of the end of that war and the setting up of the United Nations have been commemorated. Still, some states persevere in criminalising migrants by branding them as 'illegal' and 'alien'; and they are eager to deploy 
various measures of detainment and humiliation that give a false sense of legitimacy (and security) to their citizens, when in fact such measures expose a deep vulnerability. No human is illegal.

Currently, the spotlight is focused on Syria, where half of the population is displaced (11 million, including children like Aylan Kurdi). However, we cannot forget the other global hotspots: Afghanistan, Iraq, Libya and Sub-Saharan Africa. This part of Africa has a population of 1,000 million people and the highest fertility rate in the world. The region is marred not only by bloody conflicts but also by soaring temperatures and droughts. In such desperate conditions, people will continue to make the rational choice. The 'push-pull' situation will prevail. Not much has changed throughout the ages; labelling these people as illegal will not solve anything. The world needs humanitarianism, a new sense of leadership and fresh global solutions. 